\section{Healthy lifestyles and access to periodic health exams among Brazilian women}

\author{
Estilos de vida saudáveis e acesso aos exames \\ periódicos de saúde entre as mulheres brasileiras
}

Maria do Carmo Leal 1

Silvana Granado Nogueira da Gama 1

Paulo Frias 2

Célia Landmann Szwarcwald 3

\section{Introduction}

Using data from the World Health Survey carried out in Brazil in 2003, this paper has the objective of describing the sociodemographic profile of Brazilian women (age 18-69 years of age) that have adequate health care, not only with respect to health service utilization but also to healthy lifestyles. Sociodemographic variables (age, marital status, race, education level, number of household assets, and occupation), health care variables (periodic gynecologic exam with Papanicolaou, mammography among women aged 40-69 years, body mass index, smoking, alcohol, physical activity, dental care, private health insurance), and self-rated health were analyzed by municipality size strata. Logistic regression models were used to identify the characteristics of women that have adequate health care. Coverage of periodic gynecologic exam with Papanicolaou was $65.0 \%$ and mammography coverage was $47.0 \%$. Less than $20.0 \%$ of Brazilian women have adequate care, and the most associated factors were: being younger than 40 years old, having higher educational level, having private health insurance and being married. The results indicate the need to develop health promotion policies focused on modifying the risk habits and risk practices to health, and to stimulate preventive periodic health exams.

Life Style; Mammography; Vaginal Smears; Women's Health
A significant change has occurred in the role of women in contemporary society. Nowadays, it is observed an increasingly search for professional positions and careers outside of the home in addition to the responsibility of raising children 1 .

The combination of women's prior functions with new ones have brought gains to women and society as a whole. However, exhaustion caused by increase in tasks has been documented frequently, resulting in elevated levels of stress and exposure to risk behaviors in health 2 . The proportions of women who smoke, drink, and even consume illicit drugs have grown recently ${ }^{3}$. Additional problems are increased obesity, more prevalent in women, and decrease in physical activity resulting from urban life facilities 4 .

In regards to health care for women, historically, as a means of protecting the human population reproduction, health systems are structured to serve women specially during pregnancy and puerperium 5. In its turn, women's relationship with health services have always been friendlier than men's, as it is a well-recognized fact that women make use of health services more frequently 6 .

Gender disparities are also found in the perception of one's own health. It is known that women self-rate a poorer health state even though men show, comparatively for the same 
age, higher mortality rates and smaller life expectancy 7 .

Despite higher female use of health services, inequality in health care access constitutes an obstacle in disease prevention among women. Access to health services in Brazil differs by socioeconomic status and residence location 8 , presenting greater difficulty for women residing in rural areas and inland cities of small population size 9 .

Even though universal access to health services is guaranteed by the Brazilian constitution, and has been allowing the betterment of some aspects in health 10,11 , other aspects, mainly those demanding a more sophisticated medical technology for diagnosis, have shown pronounced disparities in distribution and use of available resources 12,13 .

In what concerns access to health promotion policies, another aspect that must be considered is the inequality of knowledge spread. Associated to the population's education level, it particularly affects healthy habits and lifestyles 14 .

Using data from the World Health Survey (WHS) carried out in Brazil in 2003, this article objective is to establish the characteristics of Brazilian women who have access to preventive exams for cervical and breast cancer, and to describe the sociodemographic profile of women who have adequate health care, not only from the point of view of health service use, but also in relation to healthy behaviors.

\section{Methodology}

The WHS in Brazil was carried out in 5,000 households, selected in the entire national territory with probabilistic sampling. A total of 5,000 interviews were done among individuals eighteen years or older.

The sampling was taken in three stages. In the first, 250 census tracts were selected with a probability proportional to size. The primary selection units were stratified by urban/rural situation and the municipality size $(<50,000$; 50,000-399,999; 400,000+ inhabitants). The tract socioeconomic status, established by the household head mean monthly income, was used for implicit stratification.

Twenty households were selected in each tract using an inverse sampling design. In each domicile, one resident was identified to answer questions regarding the households character- istics. Only one individual was selected (with equiprobability to answer the individual questionnaire).

The questionnaire used was translated and adapted from the original survey proposed by the World Health Organization (WHO). The following aspects were questioned: socioeconomic situation; description of health state; risk factors (smoking, alcohol, physical activity, nutrition, environmental factors); certain health problems (chronic situations - diagnosis, treatment and use of medications; severe conditions - assistance); health plan coverage such as dental care, prenatal care and infant-maternal care; user's health service response evaluation; health related family expenses, including private health plans.

Only women between 18 and 69 years of age were considered for analysis in this work. In what refers to accessibility to mammography exams, only the 40 to 69 age group was considered.

The variables used in this analysis were: (i) sociodemographic: "age group”, "educational level” (incomplete primary schooling, complete primary schooling, higher education), "race" (white, not white), "marital status" (married or with companion; single; separated or divorced; widow), "number of household assets" (summation of household assets such as refrigerator, television, stereo, washing machine, fixed telephone, cellular telephone, computer, microwave, dishwasher, 1 automobile, 2+ automobiles), "occupation” (compensated work, housewife, unemployed, retired, or disabled), and "residence municipality size" $(<50,000,50,000$ 399,999, 400,000+ inhabitants); (ii) access to health services: "private health plan" (yes; no), "gynecologic exam", "mammography", "loss of all teeth", and "dental assistance within the last year"; (iii) health lifestyle: "body mass index", "smoking habit", "alcoholic drinking", and "physical activity"; and (iv) health perception: "self-rated health".

The Body Mass Index (BMI) was measured dividing weight by the squared height $\left(\mathrm{kg} / \mathrm{cm}^{2}\right)$ and was categorized as follows: underweight (up to 18.5); normal weight (greater than or equal to 18.5 up to 25); pre-obesity (greater than or equal to 25 up to 30 ); and obesity (greater than or equal to 30 ).

Physical activity was measured by the weekly frequency and minutes taken in physical activity. Three categories were considered in the analysis: sedentary (no physical activity); in- 
sufficient physical activity (less than 150 minutes per week); sufficient physical activity (150 minutes or more per week).

Smoking habit was established by the frequency of use (has never smoked, smokes but not daily, smokes daily), while the drinking habit was studied by the consumption of alcoholic doses in the week preceding the survey. According to the WHO's criteria, excessive consumption is established by five standard doses or more in at least two days during the survey's preceding week (one standard dose corresponds to a can of beer, or a glass of draught, or a glass of wine, or a whiskey shot, or a cachaça shot, or a caipirinha).

A "health care" index was constructed through a score composed of some variables, as explained below:

- Normal weight (1 for those who have a body mass index less than 25; 0 for the others);

- Does not smoke (1 for those who do not smoke, 0 for those who smoke);

- Sufficient physical activity (1 for those who had physical activity for at least 150 minutes per week, 0 for the others);

- Does not drink excessively (1 for those who did not drink too much alcohol according to the WHO's criteria, 0 for those who did drink excessively);

- Dental conservation (1 for those who did not lose all their teeth, 0 for those who did);

- Adequate dental care in the last year (1 for those who did not need care or needed and received care, 0 for those who needed it and did not receive it);

- Adequate gynecologic exam (1 for those who had a gynecologic exam with Papanicolaou in a period of up to three years before the survey, 0 for those who never had or had an exam over three years before the survey).

- Adequate mammography (1 for those who had a mammography in a period of up to three years before the survey, 0 for those who never had one or had one over three years before the survey).

Women who answered positively to all the above items were considered to have "adequate health care".

For the statistical analysis, the data were weighted in accordance to the sampling design, using the SUDAAN software.

In the first part of the statistical analysis, the sociodemographic variables, health service access, and health promotion variables as well as self-rated health were analysed by municipality size. The chi-square test was used for testing heterogeneity of proportions.

In the second part, with the objective of identifying the characteristics of women who took periodic health exams for prevention of cervical and breast cancer, the associations of sociodemographic factors with "having a gynecologic preventive exam less than three years ago", and with "having a mammography less than three years ago" were analyzed.

Finally, a stepwise logistic regression model was used to identify the most associated factors with "having adequate health care".

\section{Results}

Table 1 shows the sociodemographic characteristics of 2,265 women between 18 and 69 years old surveyed in the study, according to the size municipality of residence. The distribution of women by age group and race is confirmed to be similar in all three municipality strata. In relation to marital status, there is a greater concentration of married women in smaller municipalities, while separated or divorced women dominate the average size and large municipalities.

The analysis by socioeconomic level (Table 1) shows that educational level is, in general, precarious, disclosing that over $50.0 \%$ of women have not completed primary schooling. There exists, however, a gradient in educational level, which improves as municipality size grows. The same gradient occurs through the categorization according to household assets. The proportion of women with private health plans is also greater in larger municipalities.

However, concerning occupational status, the differences by stratum were small (Table 1). In the total surveyed women, less than half of them are part of the work force, independent of the residence's municipality size. Among those who do not work, only $10.0 \%$ declared themselves unemployed; the others classified themselves as housewives (34.6\%), students (4.1\%), and retired (9.0\%).

Table 2 presents results relating to lifestyles and healthy habits. It is observed that over one third of all women in all three municipality groups are classified in the pre-obesity and obesity groups. About $15.0 \%$ declared they smoke daily, while there were no differences in smoking habits among the strata. On the other hand, the proportion of women who drink alcohol in excess, according to the WHO's criteria, was small $(1.5 \%)$ but with a large range varying from $0.6 \%$ in small municipalities, to $2.5 \%$ in the large population municipalities. It is also found that most women are categorized in the sufficient physical activity group (150 minutes or more), with no different patterns by stratum. 
Sociodemographic characteristics of women aged 18-69 years according to size of residence municipality. Brazil, 2003.

\begin{tabular}{|c|c|c|c|c|c|c|}
\hline \multirow[t]{2}{*}{ Variables } & \multirow[t]{2}{*}{ Categories } & \multicolumn{3}{|c|}{$\begin{array}{l}\text { Municipality population size } \\
(1,000 \text { inhabitants })\end{array}$} & \multicolumn{2}{|c|}{ Total } \\
\hline & & $\begin{array}{c}<50 \\
\%\end{array}$ & $\begin{array}{c}50-399,999 \\
\%\end{array}$ & $\begin{array}{c}400+ \\
\%\end{array}$ & $\%$ & $\mathrm{~N}$ \\
\hline \multirow[t]{4}{*}{ Age group (years) } & $18-29$ & 34.3 & 30.5 & 31.1 & 32.0 & 817 \\
\hline & $30-39$ & 22.2 & 25.0 & 23.1 & 23.5 & 599 \\
\hline & $40-49$ & 18.2 & 21.9 & 20.0 & 20.0 & 511 \\
\hline & $50+$ & 25.3 & 22.5 & 25.8 & 24.5 & 627 \\
\hline \multirow[t]{3}{*}{ Educational level* } & Incomplete fundamental & 67.1 & 52.7 & 41.3 & 53.8 & 1,374 \\
\hline & Incomplete intermediate & 11.4 & 17.9 & 17.4 & 15.5 & 396 \\
\hline & $\begin{array}{l}\text { Complete intermediate } \\
\text { or higher }\end{array}$ & 21.6 & 29.4 & 41.3 & 30.7 & 785 \\
\hline \multirow[t]{5}{*}{ Race* $^{\star}$} & White & 51.3 & 51.2 & 51.5 & 51.4 & 1,290 \\
\hline & Black & 12.4 & 8.6 & 11.6 & 10.9 & 273 \\
\hline & Yellow & 1.3 & 2.7 & 2.8 & 2.3 & 57 \\
\hline & Brown & 33.3 & 36.4 & 31.6 & 33.8 & 848 \\
\hline & Indigenous & 1.8 & 1.1 & 2.4 & 1.8 & 44 \\
\hline \multirow[t]{4}{*}{ Marital status* } & Single & 23.0 & 23.0 & 25.0 & 23.7 & 605 \\
\hline & Married/Lives with a companion & 64.5 & 60.5 & 56.5 & 60.5 & 1,547 \\
\hline & Separated/Divorced & 6.3 & 9.6 & 10.1 & 8.6 & 221 \\
\hline & Widow & 6.3 & 6.9 & 8.4 & 7.2 & 184 \\
\hline Number of household & $0-3$ & 45.3 & 26.1 & 14.8 & 28.8 & 728 \\
\hline \multirow[t]{2}{*}{ goods* } & $4-7$ & 51.0 & 65.5 & 67.7 & 61.4 & 1,550 \\
\hline & $8+$ & 3.8 & 8.3 & 17.4 & 9.8 & 248 \\
\hline \multirow[t]{9}{*}{ Occupation* } & Government employee & 8.3 & 6.9 & 4.8 & 6.7 & 171 \\
\hline & Non-government employee & 13.1 & 17.1 & 18.6 & 16.3 & 416 \\
\hline & Autonomous/Employer & 16.3 & 15.6 & 17.5 & 16.5 & 421 \\
\hline & Unpaid work & 62.3 & 60.4 & 59.0 & 60.6 & 1,548 \\
\hline & Housewife & 36.2 & 36.1 & 31.7 & 34.6 & 885 \\
\hline & Unemployed & 9.4 & 12.4 & 9.8 & 10.5 & 269 \\
\hline & Student & 3.5 & 2.5 & 6.2 & 4.1 & 104 \\
\hline & Retired & 9.8 & 7.1 & 9.8 & 9.0 & 229 \\
\hline & Other & 3.4 & 2.3 & 1.5 & 2.4 & 61 \\
\hline
\end{tabular}

* p-value $<5.0 \%\left(\chi^{2}\right.$ heterogeneity testing $)$

In regards to self-rated health, $49.0 \%$ of women perceive themselves as being in good or very good health, while $10.0 \%$ perceive a bad or very bad health. This percentage reaches its lowest value, of $7.0 \%$, among women residing in cities with over 400,000 inhabitants (Table 2).

Health conducts among women can also be analyzed by the data displayed in Table 2. Firstly, it is evidenced an important percentage of women who have lost all their original teeth (14.0\%) which is even higher in smaller municipalities $(18.0 \%)$. In regards to dental care re- ceived during the year before the interview, only $10.0 \%$ of the participants informed having had oral or dental problems without having received odontological assistance, while $65.0 \%$ declared not having looked for dental assistance since they did not feel the need.

With respect to cervical and breast preventive exams, evaluated based on gynecologic exams with Papanicolaou and mammography within the last three years, the results indicate the larger the municipality, the greater the access. In general, the coverage of gynecologic exam with $\mathrm{Pa}$ - 
Health cares among women aged 18-69 years according to size of residence municipality. Brazil, 2003.

\begin{tabular}{|c|c|c|c|c|c|c|}
\hline \multirow[t]{2}{*}{ Variables } & \multirow[t]{2}{*}{ Categories } & \multicolumn{3}{|c|}{$\begin{array}{l}\text { Municipality population size } \\
(1,000 \text { inhabitants })\end{array}$} & \multicolumn{2}{|c|}{ Total } \\
\hline & & $\begin{array}{c}<50 \\
\%\end{array}$ & $\begin{array}{c}50-399,999 \\
\%\end{array}$ & $\begin{array}{c}400+ \\
\%\end{array}$ & $\%$ & $\mathrm{~N}$ \\
\hline \multirow[t]{4}{*}{ Body mass index } & Underweight & 6.6 & 6.8 & 6.7 & 6.7 & 148 \\
\hline & Normal weight & 57.3 & 54.8 & 57.4 & 56.5 & 1,246 \\
\hline & Pre-obesity & 25.8 & 28.0 & 24.7 & 26.1 & 576 \\
\hline & Obesity & 10.4 & 10.4 & 11.1 & 10.7 & 235 \\
\hline \multirow[t]{3}{*}{ Smoking } & Daily & 13.6 & 16.3 & 14.8 & 14.9 & 380 \\
\hline & Not daily & 4.1 & 4.5 & 3.4 & 4.0 & 102 \\
\hline & Does not smoke & 82.4 & 79.2 & 81.8 & 81.1 & 2,074 \\
\hline \multirow[t]{3}{*}{ Alcoholic drinking* } & Excessively & 0.6 & 1.3 & 2.5 & 1.5 & 37 \\
\hline & Non excessively & 57.9 & 69.7 & 76.3 & 67.9 & 1,728 \\
\hline & Has never drunk & 41.5 & 29.0 & 21.2 & 30.6 & 780 \\
\hline Physical activity & Sedentary & 9.1 & 6.7 & 9.8 & 8.6 & 217 \\
\hline \multirow{2}{*}{ (per week) } & Less than $150 \mathrm{~min}$ & 10.4 & 9.4 & 11.7 & 10.5 & 267 \\
\hline & $150 \min +$ & 80.6 & 83.9 & 78.4 & 80.9 & 2,054 \\
\hline \multirow[t]{3}{*}{ Self-rated health* } & Very good/good & 44.4 & 46.0 & 55.5 & 48.6 & 1,241 \\
\hline & Average & 44.3 & 43.5 & 37.5 & 41.8 & 1,066 \\
\hline & Poor/Very poor & 11.4 & 10.6 & 6.9 & 9.6 & 246 \\
\hline Private health insurance* & Yes & 13.7 & 26.5 & 37.7 & 25.9 & 662 \\
\hline Loss of all teeth* & Yes & 17.7 & 12.5 & 11.2 & 13.8 & 353 \\
\hline \multirow[t]{3}{*}{ Dental care (per year) } & Did not need & 65.0 & 64.5 & 63.9 & 64.5 & 542 \\
\hline & Needed and received & 24.8 & 24.3 & 27.3 & 25.5 & 204 \\
\hline & Needed and did not receive & 10.2 & 11.2 & 8.8 & 10.1 & 94 \\
\hline \multirow[t]{4}{*}{ Gynecologic exam* } & $\leq 3$ years with preventive & 56.8 & 67.5 & 72.3 & 65.5 & 1,664 \\
\hline & $\leq 3$ years without preventive & 10.7 & 12.3 & 12.5 & 11.8 & 300 \\
\hline & Over 3 years & 10.2 & 8.9 & 9.8 & 9.6 & 244 \\
\hline & Never & 22.4 & 11.4 & 5.5 & 13.1 & 333 \\
\hline \multirow[t]{3}{*}{ Mammography*,** } & $\leq 3$ years & 34.4 & 43.9 & 62.3 & 47.2 & 533 \\
\hline & Over 3 years & 6.8 & 7.3 & 6.7 & 6.9 & 78 \\
\hline & Never & 58.8 & 48.8 & 31.0 & 45.9 & 519 \\
\hline Has adequate health care & Yes & 14.9 & 19.8 & 19.9 & 18.3 & 399 \\
\hline
\end{tabular}

* $p$-value $<5.0 \%\left(\chi^{2}\right.$ heterogeneity testing).

** Only for women between 40 and 69 years old.

panicolaou was ample, covering over $65.0 \%$ of women. Yet, mammography shows, in the total women, coverage much lower, $47.0 \%$, and pronounced differences between the three strata, with a range varying from $34.0 \%$ in small municipalities, to $62.0 \%$ in large municipalities (Table 2).

The data in Table 2 also reveal that less than $20.0 \%$ of women have adequate health care in every stratum, being that in the municipalities smaller than 50,000 inhabitants, the percentage is lower than $15.0 \%$.

Table 3 presents the sociodemographic differences among women that have taken, within a period of the last three years from being surveyed, preventive exams for cervical and breast cancer. In respect to the adequate gyne- 
Proportion (\%) of women who took a cervical cancer preventive exam and mammography in less than 3 years according to sociodemographic characteristics. Brazil, 2003.

\begin{tabular}{|c|c|c|c|c|c|}
\hline \multirow[t]{2}{*}{ Variables } & \multirow[t]{2}{*}{ Categories } & \multicolumn{2}{|c|}{$\begin{array}{l}\text { Preventive exam } \\
\text { for cervical cancer }\end{array}$} & \multicolumn{2}{|c|}{ Mammography* } \\
\hline & & $\%$ & $p$ value** & $\%$ & $p$ value $e^{\star \star}$ \\
\hline \multirow[t]{3}{*}{ Municipality size } & $<50,000$ & 56.8 & 0.000 & 34.2 & 0.000 \\
\hline & $50,000-399,999$ & 67.5 & & 44.1 & \\
\hline & $400,000+$ & 72.3 & & 62.3 & \\
\hline \multirow[t]{4}{*}{ Age group (years) } & $18-29$ & 53.1 & 0.000 & - & - \\
\hline & $30-39$ & 77.1 & & - & \\
\hline & $40-49$ & 75.6 & & 45.5 & NS \\
\hline & $50-69$ & 62.2 & & 48.6 & \\
\hline Had or had no children & Already had children & 64.5 & 0.000 & - & - \\
\hline among women $18-29$ years & Did not have children & 40.8 & & - & \\
\hline \multirow[t]{2}{*}{ Educational level } & Incomplete Fundamental & 60.7 & 0.000 & 36.6 & 0.000 \\
\hline & Complete Fundamental+ & 70.9 & & 70.3 & \\
\hline \multirow[t]{2}{*}{ Race } & White & 67.3 & 0.026 & 54.3 & 0.000 \\
\hline & Other & 63.5 & & 39.5 & \\
\hline \multirow[t]{2}{*}{ Marital status } & Married/Lives with a companion & 72.4 & 0.000 & 49.2 & 0.080 \\
\hline & Does not live with a companion & 54.9 & & 43.9 & \\
\hline \multirow[t]{2}{*}{ Employed and making money } & Yes & 70.7 & 0.000 & 53.2 & 0.002 \\
\hline & No & 62.0 & & 43.6 & \\
\hline \multirow[t]{3}{*}{ Number of household goods } & $0-3$ & 53.4 & 0.000 & 21.6 & 0.000 \\
\hline & $4-7$ & 67.1 & & 49.2 & \\
\hline & $8+$ & 81.1 & & 75.2 & \\
\hline \multirow[t]{2}{*}{ Health plan } & Yes & 82.1 & 0.000 & 72.3 & 0.000 \\
\hline & No & 59.6 & & 36.7 & \\
\hline
\end{tabular}

* Only for women between 40 and 69 years old.

** $\mathrm{p}$-value of the $\chi^{2}$ heterogeneity testing.

cologic exam, the data show that women in the 30-49 age group, who have a paying job, live with a partner, and reside in big cities, have the most coverage. The results also evidence accentuated inequalities by socioeconomic level, be it measured by education level or household assets. Equally, coverage is significantly larger among women who possess a private health plan. In regards to the mammography exam, the sociodemographic characteristics are similar but the social gradient is even more accentuated: coverage varies from $22.0 \%$ among women with less than four household asssets, to $75.0 \%$ among those who possess eight or more assets.

Table 4 analyzes the effects of periodic gynecologic exams over lifestyles and healthy habits, adjusted by educational level and age group. As to the habit of smoking, only the best educational level shows a significant protector effect. Regarding normal weight, the effects of age and education level were significant. In the case of excessive alcohol consumption, an inversion occurs in the effect from education level, since consumption is higher among women with a better social condition. When controlling by age and educational level, the effects of the gynecologic exam are, invariably, not significant, be it for smoking habit, excessive drinking, weight control, or physical activity. The only exception is for preventive cancer exams, which was highly associated to the gynecologic exam for every stratum.

Table 5 shows results of the logistic regression model considering, "having adequate health 
Effect of periodic gynecologic exam on healthy habits adjusted by educational level and age group. Brazil, 2003.

\begin{tabular}{|c|c|c|c|c|c|}
\hline Independent variable & Category & OR & $\mathrm{p}$-value & Adjusted OR & p-value \\
\hline & \multicolumn{5}{|c|}{ Dependent Variable: Does not smoke } \\
\hline \multirow[t]{2}{*}{ Age group (years) } & $18-39$ & 1.20 & NS & 1.00 & NS \\
\hline & $40-69$ & 1.00 & & 1.00 & \\
\hline \multirow[t]{2}{*}{ Fundamental schooling } & Incomplete & 0.49 & 0.0000 & 0.49 & 0.0000 \\
\hline & Complete & 1.00 & & 1.00 & \\
\hline Gynecologic exam with & Yes & 1.24 & NS & 1.16 & NS \\
\hline \multirow[t]{2}{*}{ Papanicolau in less than 3 years } & No & 1.00 & & 1.00 & \\
\hline & \multicolumn{5}{|c|}{ Dependent variable: Does not drink in excess } \\
\hline \multirow[t]{2}{*}{ Age group (years) } & $18-39$ & 0.69 & NS & 0.85 & NS \\
\hline & $40-69$ & 1.00 & & 1.00 & \\
\hline \multirow[t]{2}{*}{ Fundamental schooling } & Incomplete & 2.22 & 0.0218 & 2.11 & 0.0393 \\
\hline & Complete & 1.00 & & 1.00 & \\
\hline Gynecologic exam with & Yes & 0.94 & NS & 1.01 & NS \\
\hline \multirow[t]{2}{*}{ Papanicolau in less than 3 years } & No & 1.00 & & 1.00 & \\
\hline & \multicolumn{5}{|c|}{ Dependent variable: Normal weight } \\
\hline \multirow[t]{2}{*}{ Age group (years) } & $18-39$ & 2.04 & 0.0000 & 1.87 & 0.0000 \\
\hline & $40-69$ & 1.00 & & 1.00 & \\
\hline \multirow[t]{2}{*}{ Fundamental schooling } & Incomplete & 0.64 & 0.0000 & 0.75 & 0.0054 \\
\hline & Complete & 1.00 & & 1.00 & \\
\hline Gynecologic exam with & Yes & 0.92 & NS & 0.93 & NS \\
\hline \multirow[t]{2}{*}{ Papanicolau in less than 3 years } & No & 1.00 & & 1.00 & \\
\hline & \multicolumn{5}{|c|}{ Dependent variable: Regular physical activity } \\
\hline \multirow[t]{2}{*}{ Age group (years) } & $18-39$ & 1.19 & NS & 1.21 & NS \\
\hline & $40-69$ & 1.00 & & 1.00 & \\
\hline \multirow[t]{2}{*}{ Fundamental schooling } & Incomplete & 0.98 & NS & 1.06 & NS \\
\hline & Complete & 1.00 & & 1.00 & \\
\hline Gynecologic exam with & Yes & 1.17 & NS & 1.19 & NS \\
\hline \multirow[t]{2}{*}{ Papanicolau in less than 3 years } & No & 1.00 & & 1.00 & \\
\hline & \multicolumn{5}{|c|}{$\begin{array}{l}\text { Dependent variable: Had a mammography } \\
\text { in less than } 3 \text { years (women } 40-69 \text { ) }\end{array}$} \\
\hline \multirow[t]{2}{*}{ Fundamental schooling } & Incomplete & 0.24 & 0.0000 & 0.31 & 0.0000 \\
\hline & Complete & 1.00 & & 1.00 & \\
\hline Gynecologic exam with & Yes & 7.11 & 0.0000 & 6.03 & 0.0000 \\
\hline Papanicolau in less than 3 years & No & 1.00 & & 1.0 & \\
\hline
\end{tabular}

care" as the dependent variable. Using a stepwise variable selection process, the statistical analysis indicates that being younger than 40 years, having a better education level, having a private health plan, and being married or living with a companion are the factors most associated to the response variable. The effects of the variables for "number of household assets", "race", "employment", and "municipality stratum" were not statistically significant.

\section{Discussion}

The sociodemographic profile for the female population aged 18 to 69 years, pictured from the WHS data, shows that Brazilian women still have a small participation in the work force, and, the majority, are married or live with a companion. In general, they present a precarious educational level and low purchase power, characteristics that also improve with municipality size. 
Results of the logistic regression considering "having adequate health care" as the response variable. Brazil, 2003

\begin{tabular}{|c|c|c|c|c|c|}
\hline Independent variable & Category & OR & p-value & Adjusted OR & p-value \\
\hline \multirow[t]{3}{*}{ Age group (years) } & $18-29$ & 2.23 & 0.0000 & 2.12 & 0.0000 \\
\hline & $30-39$ & 2.92 & 0.0000 & 2.54 & 0.0000 \\
\hline & $40+$ & 1.00 & - & 1.00 & - \\
\hline \multirow[t]{3}{*}{ Educational level } & Incomplete fundamental & 0.33 & 0.0000 & 0.37 & 0.0000 \\
\hline & Incomplete intermediate & 0.59 & 0.0015 & 0.58 & 0.0032 \\
\hline & $\begin{array}{l}\text { Complete intermediate } \\
\text { or higher }\end{array}$ & 1.00 & - & 1.00 & - \\
\hline \multirow[t]{2}{*}{ Married or lives with a companion } & Yes & 1.61 & 0.0007 & 2.02 & 0.0000 \\
\hline & No & 1.00 & - & 1.00 & - \\
\hline \multirow[t]{2}{*}{ Private health insurance } & Yes & 1.38 & 0.0000 & 1.22 & 0.0105 \\
\hline & No & 1.00 & - & 1.00 & - \\
\hline
\end{tabular}

Regarding healthy habits, results indicate that the frequency in overweight and obesity disorders associated to higher burden of chronic diseases and disabilities, showed a stability trend, with similar values to those reported by the National Health and Nutrition Survey (PNSN - Pesquisa Nacional de Saúde e Nutrição) taken in 1989 15, after two decades of growing 16.

In a global analysis, overweight, in Brazil, does not constitute as serious a problem as in countries like the United States, where obesity percentages have reached levels over $30.0 \%$ among women aged 20 and 74 years, during the period 1999-2002 17. However, the overweight problem can no longer be attributed only to groups of higher socioeconomic status, as has been discussed by Monteiro et al. 16. The Brazilian WHS data show that overweight occurs uniformly throughout the country, independent of municipality size.

Tobacco use, one of the main causes of premature mortality, of diseases and disabilities, showed in the female Brazilian population a slightly smaller proportion than that found among North American women 18, and tending to decrease if compared to results obtained in 1989 by means of the PNSN 19. The daily percentage for smoking, $15.0 \%$, obtained for the stratum of municipalities larger than 400 thousand inhabitants, is similar to the level found in most of the country capitals in a recent survey done by the National Cancer Institute (INCA - Instituto Nacional de Câncer) 20, with exception for the southern capitals, which showed smoking proportions above $20.0 \%$ among women aged 15 years old and over.
Contrary to smoking, society and its means of mass communication continue motivating the use of alcohol in social events, starting at adolescence 20 . The WHS revealed that the great majority of Brazilian women drink socially but the excessive alcohol consumption did not configure as an important matter, corresponding to $1.5 \%$ of all women, in a much smaller proportion than that found in France, where, according to the WHO's data (http://www3.who. $\mathrm{int} /$ whosis/alcohol, accessed on 18/Jan/2005), the percentage of women that drink excessively surpasses $10.0 \%$.

Regular physical exercise is considered a protective factor for health 21 . Results in the present survey indicate high frequencies of women who practice regular physical activities when compared to those obtained from a recent national survey taken in the Brazilian capitals 20 , maybe because in the WHS, the questions referred as much to physical exercise for pleasure as to those practiced at work, including domestic work.

As regards the analysis of the coverage of cervical cancer prevention exam, it cannot be left unregistered that a significant portion of Brazilian women benefit from this service, with an adequate time interval between exams. Knowing that cervical cancer presents a high potential of being cured, especially when diagnosed and treated at an early stage 22 , this result is very positive.

However, besides inequality in access to periodic gynecologic exams according to municipality size, two other aspects deserve specific 
attention. The first one relates to the lack of influence of the periodic gynecologic exam or healthy behaviors, since the effects of regular gynecologic exam (adjusted by educational level and age group) were not significantly associated to smoking, excessive drinking, weight control, or practicing physical activities. These results possibly express failure in integral attention towards the woman and the lost opportunities to promote healthy habits, limiting the possibilities of reducing incidence of chronic diseases ${ }^{3}$. The second aspect concerns the life phase that women begin gynecologic exams. The WHS data show that coverage is significantly higher among young women who have already given birth. Given that sexual activity begins at increasingly younger ages in Brazil, women's delayed entry into the health system constitutes an obstacle for detection, treatment, and prevention of sexually transmitted diseases in the young female population 23 .

The Brazilian WHS results revealed that coverage for mammography exams are low, reaching less than half of Brazilian women between the age 40 and 69 years. Even though the recommended age group in Brazil to start routine exams is 50 to 59 years, over $40.0 \%$ of women in this age group have never undergone one of these exams. Important gradients were found by municipality size, possibly resulting from the concentration of medical diagnosis services in the capitals and large scale municipalities. According to information from the Medical-Sanitary Assistance Survey (Pesquisa Assistência Médico-Sanitária) (http://tabnet.data sus.gov.br/cgi/ams/amsopcao.htm, accessed on $27 /$ Jan/2005), done in 2002, the capitals withhold $43.0 \%$ of the mammographies but only $26.0 \%$ of the female population between 40 and 69 years old.

Still related to mammography, a pronounced coverage differential is observed according to form of payment for this kind of service. Coverage reaches $72.0 \%$ in the group of women that have private health insurance, at the same uti- lization level of North American women 24, but the double of that found in the group of women who use public services. It is only recently that the Ministry of Health began recommending the mammography as the exam for the breast cancer diagnosis, which may be one of the explanatory factors for the low coverage in the public health system.

Inequalities in access to cervical and breast cancer diagnoses, have been well-documented in international literature. In general, they are associated with low education levels 25 , to the geographic imbalance in service distribution 26 , and accentuated by the user's purchase power, be it by means of the private health insurance or service direct payment 27 .

Although having a universal character, SUS lacks, to this day, mechanisms that are, in fact, efficient, in a way as to make certain services, available in larger municipalities, also accessible to the resident population of small municipalities and of lower socioeconomic status. As concerns dental health, the difficulty in access perceived by PNAD 1998 data still persist. Further more, data from the WHS show that only $18.0 \%$ of Brazilian women have adequate health care, and that this proportion is at the $10.0 \%$ level among women who live in small municipalities and have incomplete schooling.

Among the explanatory mechanisms of the low coverage for the set of adequate health conducts in the Brazilian female population, are those related to unequal access to the offered services and the lost opportunities to promote healthy behaviors at the moment of service utilization, together with a persistently precarious educational level in most women.

Results for the present analysis indicate a need to develop health promotion policies directed to the female population so as to modify health risk habits and practices, motivate periodic preventive exams, and reduce inequalities in accessibility by means of the decentralization, in strategies, specifically, directed towards overcoming social exclusion. 


\section{Resumo}

Utilizando os dados da Pesquisa Mundial de Saúde (PMS), realizada no Brasil em 2003, objetiva-se descrever o perfil sócio-demográfico das mulheres brasileiras entre 18 e 69 anos que têm cuidados adequados com a sua saúde, não só quanto à utilização de serviços, mas também aos comportamentos saudáveis. As variáveis sócio-demográficas (idade, situação conjugal, grau de instrução, bens no domicílio e cor da pele), de cuidados com a saúde (exame ginecológico com Papanicolau, mamografia em mulheres de 40 a 69 anos, índice de massa corpórea, fumo, álcool, atividade física, saúde oral, plano privado) e auto-avaliação da saúde foram analisadas segundo estrato de tamanho do município. Utilizando modelos de regressão logística foram identificadas as características das mulheres que têm cuidados adequados com a sua saúde. A cobertura do exame ginecológico periódico com Papanicolaou foi de 65,0\% enquanto a da mamografia foi de 47,0\%. Menos do que 20,0\% das mulheres têm cuidados adequados com a saúde, sendo que os fatores mais associados foram: ter menos de quarenta anos, melhor grau de instrução, plano de saúde e ser casada. Os resultados indicam a necessidade do desenvolvimento de políticas direcionadas a modificar os hábitos $e$ práticas de risco à saúde e incentivar os exames preventivos periódicos.

Estilo de Vida; Mamografia; Esfregaço Vaginal; Saúde da Mulher

\section{Contributors}

M. C. Leal participated from the project's development, through fieldwork, to the data analysis and was the article's main author. S. G. N. Gama participated from the project's development, through fieldwork, to the data analysis, and participated in the article's writing and bibliographic documentation. P. Frias participated from the project's development, through fieldwork, to data analysis and discussion of the article's results. C. L. Szwarcwald coordinated the research, was responsible for the study's sample, creating the index used in the article, and final revisions.

\section{Acknowledgments}

The present work had financial support from the Conselho Nacional de Desenvolvimento Científico e Tecnológico (CNPq; National Counsel for Scientific Development and Technology) and from the Departamento de Ciência e Tecnologia (DECIT; Department of Science and Technology), Ministério da Saúde (Ministry of Health).

\section{References}

1. Lahelma E, Arber S, Kivela K, Roos E. Multiple roles and health among British and Finnish women: the influence of socioeconomic circumstances. Soc Sci Med 2002; 54:727-40.

2. Griffin JM, Fuhrer R, Stansfeld SA, Marmot M. The importance of low control at work and home on depression and anxiety: do these effects vary by gender and social class? Soc Sci Med 2002; 54:783-98.

3. van der Wilk EA, Jansen J. Lifestyle-related risks: are trends in Europe converging? Public Health 2005; 119:55-66.

4. Mack KA, Ahluwalia IB. Observations from the CDC: Monitoring women's health in the United States: selected chronic disease indicators, 1991-2001 BRFSS. J Womens Health (Larchmt) 2003; 12:309-14.

5. Martins APV. Visões do feminino: a medicina da mulher nos séculos XIX e XX. Rio de Janeiro: Editora Fiocruz; 2004.

6. Travassos C, Viacava F, Pinheiro R, Brito A. Utilization of health care services in Brazil: gender, family characteristics, and social status. Rev Panam Salud Publica 2002; 11:365-73.

7. Denton M, Prus S, Walters V. Gender differences in health: a Canadian study of the psychological, structural and behavioral determinants of health. Soc Sci Med 2004; 58:2585-600.

8. Leal MD, Gama SG, Cunha CB. Desigualdades raciais, sociodemográficas, e na assistência ao pré-natal e ao parto, 1999-2001. Rev Saúde Pública 2005; 39:100-7.

9. Quadros CA, Victora CG, Costa JS. Coverage and focus of a cervical cancer prevention program in southern Brazil. Rev Panam Salud Publica 2004; 16:223-32

10. Monteiro CA, Franca Junior I, Conde WL. Evolução da assistência materno-infantil na cidade de São Paulo (1984-1996). Rev Saúde Pública 2000; 34:19-25.

11. Pinho AA, Franca Junior I, Schraiber LB, D'Oliveira AFPL. Cobertura e motivos para a realização ou não do teste de Papanicolaou no Município de São Paulo. Cad Saúde Pública 2003; 19 Suppl 2:S303-13.

12. Souza Junior PR, Szwarcwald CL, Barbosa Junior A, Carvalho MF, Castilho EA. Infecção pelo HIV durante a gestação: estudo-Sentinela Parturiente, Brasil, 2002. Rev Saúde Pública 2004; 38:764-72.

13. Molina L, Dalben I, De Luca LA. Análise das oportunidades de diagnóstico precoce para as neoplasias malignas de mama. Rev Assoc Med Bras 2003; 49:185-90.

14. Millar WJ, Stephens T. Social status and health risks in Canadian adults: 1985 and 1991. Health Rep 1993; 5:143-56.

15. Coitinho DC, Leão MM, Recine E, Sichieri R. Condições nutricionais da população brasileira: Adultos e idosos - Pesquisa Nacional sobre Saúde e Nutrição. Brasília: Instituto Nacional de Alimentação e Nutrição; 1991.

16. Monteiro CA, Conde WL, Popkin BM. The burden of disease from undernutrition and overnutrition in countries undergoing rapid nutrition transition: a view from Brazil. Am J Public Health 2004; 94:433-4. 
17. National Center for Health Statistics. Health, United States, 2004. With chartbook on trends in the health of Americans. Hyattsville: National Center for Health Statistics; 2004.

18. Pleis JR, Schiller JS, Benson V. Summary health statistics for U.S. adults: National Health Interview Survey, 2000. Vital Health Stat 10 2003; (215):1132.

19. Instituto Nacional de Alimentação e Nutrição. Pesquisa Nacional sobre Saúde e Nutrição: perfil de crescimento da população brasileira de 0 a 25 anos. Brasília: Instituto Nacional de Alimentação e Nutrição; 1990.

20. Instituto Nacional de Câncer. Inquérito domiciliar sobre comportamentos de risco e morbidade referida de doenças e agravos não transmissíveis. Brasil, 15 capitais e Distrito Federal, 2002-2003. Rio de Janeiro: Instituto Nacional de Câncer; 2004.

21. World Health Organization. The World Health Report 2002: reducing risks, promoting healthy life. Geneva: World Health Organization; 2002.

22. Sankaranarayanan R, Budukh AM, Rajkumar R. Effective screening programmes for cervical cancer in low- and middle-income developing countries. Bull World Health Organ 2001; 79:954-62.
23. Miranda AE, Szwarcwald CL, Peres RL, Page-Shafer K. Prevalence and risk behaviors for chlamydial infection in a population-based study of female adolescents in Brazil. Sex Transm Dis 2004; 31: 542-6.

24. Coughlin SS, Uhler RJ, Bobo JK, Caplan L. Breast cancer screening practices among women in the United States, 2000. Cancer Causes Control 2004; 15:159-70.

25. Borras JM, Guillen M, Sanchez V, Junca S, Vicente R. Educational level, voluntary private health insurance and opportunistic cancer screening among women in Catalonia (Spain). Eur J Cancer Prev 1999; 8:427-34.

26. Agurto I, Bishop A, Sanchez G, Betancourt Z, Robles S. Perceived barriers and benefits to cervical cancer screening in Latin America. Prev Med 2004; 39:91-8.

27. Hayward RA, Shapiro MF, Freeman HE, Corey CR. Who gets screened for cervical and breast cancer? Results from a new national survey. Arch Intern Med 1988; 148:1177-81.

28. Barros AJD, Bertoldi AD. Desigualdades na utilização e no acesso a serviços odontológicos: uma avaliação em nível nacional. Ciênc Saúde Coletiva 2002; 7:709-17.

Submitted on 04/May/2005

Final version resubmitted on 18/Oct/2005

Approved on 19/Oct/2005 